\title{
Comparison of palonosetron with ondansetron in prevention of postoperative nausea and vomiting in patients receiving intravenous patient-controlled analgesia after gynecological laparoscopic surgery
}

\author{
Yu Yil Kim, Soo Yeong Moon, Dong Un Song, Ki Hyun Lee, Jae Wook Song, and Young Eun Kwon \\ Department of Anesthesiology and Pain Medicine, Presbyterian Medical Center, Jeonju, Korea
}

Background: Postoperative nausea and vomiting (PONV) are common complications after anesthesia and surgery. This study was designed to compare the effects of palonosetron and ondansetron in preventing PONV in high-risk patients receiving intravenous opioid-based patient-controlled analgesia (IV-PCA) after gynecological laparoscopic surgery.

Methods: One hundred non-smoking female patients scheduled for gynecological laparoscopic surgery were randomly assigned into the palonosetron group $(n=50)$ or the ondansetron group $(n=50)$. Palonosetron $0.075 \mathrm{mg}$ was injected as a bolus in the palonosetron group. Ondansetron $8 \mathrm{mg}$ was injected as a bolus and $16 \mathrm{mg}$ was added to the IV-PCA in the ondansetron group. The incidences of nausea, vomiting and side effects was recorded at $2 \mathrm{~h}, 24 \mathrm{~h}$, $48 \mathrm{~h}$ and $72 \mathrm{~h}$, postoperatively.

Results: There were no significant differences between the groups in the incidence of PONV during $72 \mathrm{~h}$ after operation. However, the incidence of vomiting was lower in the palonosetron group than in the ondansetron group ( $18 \%$ vs. $4 \%, \mathrm{P}=0.025)$. No differences were observed in use of antiemetics and the side effects between the groups.

Conclusions: The effects of palonosetron and ondansetron in preventing PONV were similar in high-risk patients undergoing gynecological laparoscopic surgery and receiving opioid-based IV-PCA. (Korean J Anesthesiol 2013; 64: 122-126)

Key Words: Intravenous patient-controlled analgesia, Ondansetron, Palonosetron, Postoperative nausea and vomiting.

Received: May 22, 2012. Revised: 1st, June 7, 2012; 2nd, June 13, 2012. Accepted: June 14, 2012.

Corresponding author: Yu Yil Kim, M.D., Department of Anesthesiology and Pain Medicine, Presbyterian Medical Center, 300, Junghwasandong 1-ga, Wansan-gu, Jeonju 560-750, Korea. Tel: 82-63-230-1594, Fax: 82-63-230-1599, E-mail: gangoaogi@naver.com

(c) This is an open-access article distributed under the terms of the Creative Commons Attribution Non-Commercial License (http:// creativecommons.org/licenses/by-nc/3.0/), which permits unrestricted non-commercial use, distribution, and reproduction in any medium, provided the original work is properly cited. 


\section{Introduction}

The use of opioid-based intravenous-patient controlled analgesia (IV-PCA) for controlling postoperative pain has become widespread. Yet while IV-PCA is effective in controlling postoperative pain, continuous administration of opioid can cause or aggravate postoperative nausea and vomiting (PONV).

PONV, like postoperative pain, is a complication that delays recovery, prolongs hospital stays, and increases costs due to additional drug use [1]. PONV is the most common reason why patients choose to stop IV-PCA.

Thus there have been many studies on methods and drugs to prevent PONV. The 5-Hydroxytryptamine $\left(5-\mathrm{HT}_{3}\right)$ receptor antagonist is being commonly used because it is more effective in PONV prevention and treatment than other antiemetics and has few side effects [2]. Among $5-\mathrm{HT}_{3}$ receptor antagonists, ondansetron is the most widely used drug, granisetron and ramosetron are also used. Recently, palonosetron has been reported to be effective against chemotherapy-induced nausea and vomiting $[3,4]$ and effective in the prevention of PONV $[5,6]$.

Palonosetron is a newly developed $5-\mathrm{HT}_{3}$ receptor antagonist. Its receptor-affinity is more potent than other antagonists. Its plasma half-life is very long $[7,8]$, Also it is known to be more effective than ondansetron against nausea and vomiting in patients using anticancer drugs [4]. However, studies comparing the effects of preventing PONV between palonosetron and other $5-\mathrm{HT}_{3}$ receptor antagonists are sparse.

Thus we compared the effects of palonosetron and ondansetron in PONV prevention in patients who underwent laparoscopic gynecological surgery and used IV-PCA after surgery.

\section{Materials and Methods}

The subjects of the present study were 100 American Society of Anesthesiologists physical status I and II female non-smoker patients aged 18 years and above, scheduled for gynecological laparoscopic surgery, with no history of PONV or motion sickness. Patients were excluded from the study if they had diseases in the major organs, were pregnant, vomited or taken antiemetics within $24 \mathrm{~h}$ before surgery, or if they were allergic to the study drugs. We launched the prospective study upon receiving approval from the Institutional Review Board of the Presbyterian Medical Center, Jeonju, North Jeolla Province, Republic of Korea and received informed consent from the patients.

All patients were kept in the NPO state for $8 \mathrm{~h}$ or longer. The patients did not receive premedication. General anesthesia was induced with propofol $1.5-2 \mathrm{mg} / \mathrm{kg}$ and remifentanil $1 \mu \mathrm{g} / \mathrm{kg}$. Tracheal intubation was facilitated with rocuronium $0.8-1 \mathrm{mg} /$ $\mathrm{kg}$. Anesthesia was maintained with sevoflurane $1.5-3$ vol\%, $\mathrm{O}_{2}-\mathrm{N}_{2} \mathrm{O} 3 \mathrm{~L} / \mathrm{min}\left(\mathrm{FiO}_{2} 0.5\right)$, and remifentanil $0.05-0.1 \mu \mathrm{g} / \mathrm{kg} /$ min. Heart rate and blood pressure were kept in the $20 \%$ range of base-line before anesthesia. Mechanical ventilation was performed so that $\mathrm{P}_{\mathrm{ET}} \mathrm{CO}_{2}$ was $30-35 \mathrm{mmHg}$. When the surgery was over, pyridostigmine and glycopyrrolate were used for reversing muscle relaxation. The patient was extubated with the return of consciousness and the stabilization of spontaneous breathing.

The patients were randomly assigned to the ondansetron group $(n=50)$ and the palonosetron group $(n=50)$. In the ondansetron group, ondansetron $8 \mathrm{mg}$ ( $4 \mathrm{ml}$ ) was i.v. administered as a bolus injection immediately before anesthesia induction. Ondansetron $16 \mathrm{mg}(8 \mathrm{ml})$ was added in IV-PCA and was continuously infused. In the palonosetron group, palonosetron $0.075 \mathrm{mg}$ ( $4 \mathrm{ml}$ ) was i.v. administered immediately before anesthesia induction and normal saline $8 \mathrm{ml}$ was added to the IV-PCA. In both groups, fentanyl $600 \mu \mathrm{g}$ and ketorolac 240 mg were diluted with normal saline $100 \mathrm{ml}$. The basal rate for IV-PCA was $2 \mathrm{ml} / \mathrm{h}$, bolus injection was $2 \mathrm{ml}$, and the lockout time was set at $15 \mathrm{~min}$. Both groups used identical syringes for bolus intravenous injection and the same type of IV-PCA machine. Fifteen min before the end of the surgery, continuous intravenous administration of remifentanil was discontinued and IV-PCA was infused. After the surgery, if the patient wanted additional analgesics, ketorolac $30 \mathrm{mg}$ was given.

$2 \mathrm{~h}$ after the surgery (recovery room), $24 \mathrm{~h}, 48 \mathrm{~h}, 72 \mathrm{~h}$, an anesthesiologist, blinded to group assignment, visited the patients and assessed whether or not the patients had nausea and vomiting. Nausea was defined as a subjectively unpleasant feeling associated with the awareness of the urge to vomit. Vomiting was defined as an actual physical phenomenon of the forceful expulsion of gastric contents from the mouth. Retching was defined as labored, spasmodic contractions of the respiratory muscle without expulsion of gastric contents. If the patient retched and had the symptoms of vomiting, it was counted as vomiting. Side-effects of $5-\mathrm{HT}_{3}$ receptor antagonists, which are headache, dizziness, drowsiness were also evaluated. If the patient wanted treatment for continuous PONV, metoclopramide $10 \mathrm{mg}$ was additionally i.v. administered.

For the sample size for the two groups, the power was set at $80 \%(\beta=0.2)$ with a $30 \%$ reduction of PONV incidence. The significant level was set as $5 \%(\alpha=0.05$, two-tailed). The calculated sample size was minimum 42 , so taking potential drop-outs into consideration, the sample size was set as 50 for each group $[5,9]$.

SPSS 14.0 was used for statistical analysis (SPSS, Inc, an IBM Company, Chicago, Illinois, USA). The patients' age, height, weight, and anesthesia time were analyzed using the independent t-test. The incidence of PONV was analyzed using chi-square test and Fisher's exact test. Null hypotheses of no difference were rejected if $P$ values were less than 0.05 . 
Table 1. Patient Characteristics and Duration of Anesthesia

\begin{tabular}{lcc}
\hline & $\begin{array}{c}\text { Ondansetron } \\
\text { group } \\
(\mathrm{n}=50)\end{array}$ & $\begin{array}{c}\text { Palonosetron } \\
\text { group } \\
(\mathrm{n}=50)\end{array}$ \\
\hline Age (yr) & $41.1 \pm 11.3$ & $43.0 \pm 11.2$ \\
Height (cm) & $156.3 \pm 6.0$ & $155.9 \pm 6.4$ \\
Weight (kg) & $60.2 \pm 9.3$ & $56.9 \pm 11.2$ \\
Duration of anesthesia (min) & $113.0 \pm 31.7$ & $116.0 \pm 41.3$ \\
\hline
\end{tabular}

Values are mean \pm SD. No statistically significant differences between the groups ( $\mathrm{P}>0.05)$; Independent t-test.

Table 2. Incidence of Postoperative Nausea and Vomiting (PONV) and Need for Rescue Antiemetics

\begin{tabular}{lccc}
\hline & $\begin{array}{c}\text { Ondansetron } \\
\text { group } \\
(\mathrm{n}=50)\end{array}$ & $\begin{array}{c}\text { Palonosetron } \\
\text { group } \\
(\mathrm{n}=50)\end{array}$ & P value \\
\hline 0-2 h & & & \\
Nausea & $13(26.0)$ & $6(12.0)$ & 0.074 \\
Vomiting & $2(4.0)$ & $1(2.0)$ & 0.558 \\
PONV & $13(26.0)$ & $6(12.0)$ & 0.074 \\
Rescue antiemetics & $4(8.0)$ & $4(8.0)$ & 1.000 \\
2-24 h & & & \\
Nausea & $16(32.0)$ & $20(40.0)$ & 0.405 \\
Vomiting & $5(10.0)$ & $2(4.0)$ & 0.240 \\
PONV & $16(32.0)$ & $20(40.0)$ & 0.405 \\
Rescue antiemetics & $8(16.0)$ & $6(12.0)$ & 0.564 \\
$0-24 \mathrm{~h}$ & & & \\
Nausea & $19(38.0)$ & $22(44.0)$ & 0.542 \\
Vomiting & $7(14.0)$ & $2(4.0)$ & 0.081 \\
PONV & $20(40.0)$ & $22(44.0)$ & 0.685 \\
Rescue antiemetics & $10(20.0)$ & $10(20.0)$ & 1.000 \\
$24-72 \mathrm{~h}$ & & & \\
Nausea & $20(40.0)$ & $13(34.0)$ & 0.137 \\
Vomiting & $2(4.0)$ & $0(0.0)$ & 0.495 \\
PONV & $20(40.0)$ & $13(26.0)$ & 0.137 \\
Rescue antiemetics & $8(16.0)$ & $4(8.0)$ & 0.218 \\
$0-72 \mathrm{~h}$ & & & \\
Nausea & $25(50.0)$ & $24(48.0)$ & 0.841 \\
Vomiting & $9(18.0)$ & $2(4.0)^{*}$ & 0.025 \\
PONV & $26(52.0)$ & $24(48.0)$ & 0.689 \\
Rescue antiemetics & $14(28.0)$ & $13(26.0)$ & 0.822 \\
\hline
\end{tabular}

Values are number of patients (\%). ${ }^{*} \mathrm{P}<0.05$ for the palonosetron group compared with ondansetron group; Fisher's exact test.

\section{Results}

The study enrolled 100 patients until completion with no drop-outs.

There were no significant differences between the two groups in patient characteristics and anesthesia time (Table 1).

The PONV incidence rates for each of the set times were similar in the two groups. There was no difference in the total incidence rates of PONV in $0-72 \mathrm{~h}$ (52\% for the ondansetron group, $48 \%$ for the palonosetron group). The incidence rate for vomiting was significantly lower in the ondansetron group than
Table 3. Incidence of Adverse Events

\begin{tabular}{lcc}
\hline & $\begin{array}{c}\text { Ondansetron group } \\
(\mathrm{n}=50)\end{array}$ & $\begin{array}{c}\text { Palonosetron group } \\
(\mathrm{n}=50)\end{array}$ \\
\hline Headache & $14(28)$ & $7(14)$ \\
Dizziness & $15(30)$ & $11(22)$ \\
Drowsiness & $5(10)$ & $6(12)$ \\
\hline
\end{tabular}

Values are number of patients (\%). No statistically significant differences between the groups $(\mathrm{P}>0.05)$; Chi-square test.

the palonosetron group ( $18 \%$ vs. $4 \%, \mathrm{P}=0.025)$. There was no difference in the use of additional antiemetics between the two groups (Table 2).

There were postoperative side-effects such as headache, dizziness, and drowsiness, but they did not differ significantly between the ondansetron group and the palonosetron group (Table 3).

\section{Discussion}

PONV is a complication that causes discomfort and dissatisfaction in patients who undergo surgery. There are many methods for its prevention and treatment. Nevertheless the incidence rate of PONV is $20-30 \%$. It is affected by factors related to surgery, anesthesia, and the patient [1]. Apfel et al. [10] stated that among patients receiving inhaled anesthesia, female, a history of PONV or motion sickness, non-smoker, and postoperatively using opioid were the more important risk factors of PONV, and each additional risk factor increased the PONV incidence rate to $21,39,61$, and $79 \%$.

The boundary of the present study was restricted to female non-smoker who used opioids for IV-PCA. These patients belonged to the high risk group since they had three of the risk factors listed by Apfel et al. [10] and had laparoscopic surgery, which is known for a high incidence of PONV. So they were expected to have a high PONV incidence rate $[11,12]$. Thus on an ethical reasons, the study did not include a control group.

Opioid-based IV-PCA is a safe method for managing postoperative pain with a high rate of satisfaction because the patient self-infuses additional doses when necessary and keeps the drug's plasma concentration stable [13]. However, postoperative opioid use had caused PONV in many studies [10]. When PONV occurs while using IV-PCA, patients do not infuse adequate doses for pain control [14]. Sometimes patients voluntarily stop PCA, so antiemetics are used for PONV prevention.

Many types of 5- $\mathrm{HT}_{3}$ receptor antagonists are being currently used to prevent PONV. It affects the receptors of $5-\mathrm{HT}_{3}$ in the mucous membrane of the stomach and the central chemoreceptor trigger zone and suppresses nausea and vomiting. 
Among them, ondansetron is the most widely used type [15].

Palonosetron is a second generation serotonin $5-\mathrm{HT}_{3}$ receptor antagonist. Unlike other antagonists, it has unique structural, pharmacological, clinical characteristics. Other antagonists directly compete with serotonin, but palonosetron has an indirect effect by its allosteric binding with $5-\mathrm{HT}_{3}$ receptors [16]. Also it suppresses the response induced by substance $\mathrm{P}$, has negative cooperativity with neurokinin-1 receptors by cross-talk, and creates an antiemetic effect [17]. These explain strong receptor-affinity of palonosetron and its long plasma half-life.

In high-risk groups for PONV such as in the present study, combination treatments such as TIVA with propofol and other drugs are recommended [18]. However, the present study aimed at comparing the effects of two drugs, so combination preventive methods could not be used. Instead, extensive literature was reviewed to find and use the method that best prevents PONV [5,6,9,19-21]. There have been many studies on optimal dose and usage of ondansetron. Generally an iv. injection of $8 \mathrm{mg}$ is suggested as appropriate [19]. There are reports that when using opioid-based IV-PCA, adding ondansetron decreases PONV [20,21]. Palonosetron 0.075 $\mathrm{mg}$ is reported to be more effective in PONV prevention than $0.025 \mathrm{mg}$ and $0.050 \mathrm{mg}[5,6]$. The findings of the studies above were collated so that in the present study, ondansetron $8 \mathrm{mg}$ was infused as a bolus and $16 \mathrm{mg}$ was added to IV-PCA and continuously infused. Palonosetron $0.075 \mathrm{mg}$ was infused as a bolus.

Recently there have been studies comparing the effects of palonosetron and other $5-\mathrm{HT}_{3}$ receptor antagonists on PONV prevention [22-24]. Park and Cho [22] studied the use of ondansetron $8 \mathrm{mg}$ and palonosetron $0.075 \mathrm{mg}$ before anesthesia induction on patients with two or more risk factors. Palonosetron (42.2\%) was far better than ondansetron (66.7\%) in PONV prevention up to $24 \mathrm{~h}$. Moon et al. [23] compared the effects of ondansetron and palonosetron in PONV prevention in high-risk patients with three or more risk factors. Similar to the present study, ondansetron was added to IV-PCA. As a result, palonosetron was far more effective than ondansetron in PONV prevention for $2-24 \mathrm{~h}$ ( $42 \%$ vs. $62 \%$ ). However, in the present study the PONV incidence rates were similar in the palonosetron group (48\%) and the ondansetron group (52\%). But similar to the preventive effects found in other studies, the PONV incidence rate up to $24 \mathrm{~h}$ for the palonosetron group was $44 \%$. In the present study, the method used in the ondansetron group (which used $8 \mathrm{mg}$ as i.v. bolus and continuous iv. infusion of $16 \mathrm{mg}$ addition in IV-PCA) was noteworthy in its remarkable effect in PONV prevention.

Palonosetron, as a 5- $\mathrm{HT}_{3}$ receptor antagonist, also has sideeffects such as headache, dizziness, and drowsiness. In the present study the two groups showed no difference in the incidence of side-effects. Recently the US FDA has warned against the use of ondansetron, which like droperidol, can cause severe heart complications such as QTc interval prolongation. But palonosetron is not known to have such severe side effects [7].

For ethical reasons, this study did not include a control group using placebos for high-risk patients for PONV. Thus the present study is limited in the sense that it could not defind the base incidence rate for PONV in this particular procedure. Another limitations of the present study is that equipotent doses of the two drugs were not used; instead optimal doses were used for comparisons. For further study, these limitations need to be addressed and many other methods should be used with a large patient size.

In conclusion, bolus of palonosetron $0.075 \mathrm{mg}$ had preventive effects on PONV similar to a bolus of ondansetron $8 \mathrm{mg}$ and continuous i.v. administration of an addition of ondansetron $16 \mathrm{mg}$ in the IV-PCA in high-risk patients who were using IV-PCA after gynecological laparoscopic surgery.

\section{References}

1. Watcha MF, White PF. Postoperative nausea and vomiting. Its etiology, treatment, and prevention. Anesthesiology 1992; 77: 16284.

2. Gan TJ, Meyer T, Apfel CC, Chung F, Davis PJ, Eubanks S, et al. Consensus guidelines for managing postoperative nausea and vomiting. Anesth Analg 2003; 97: 62-71.

3. Eisenberg P, MacKintosh FR, Ritch P, Cornett PA, Macciocchi A. Efficacy, safety and pharmacokinetics of palonosetron in patients receiving highly emetogenic cisplatin-based chemotherapy: a doseranging clinical study. Ann Oncol 2004; 15: 330-7.

4. Aapro MS, Grunberg SM, Manikhas GM, Olivares G, Suarez T, Tjulandin SA, et al. A phase III, double-blind, randomized trial of palonosetron compared with ondansetron in preventing chemotherapy-induced nausea and vomiting following highly emetogenic chemotherapy. Ann Oncol 2006; 17: 1441-9.

5. Kovac AL, Eberhart L, Kotarski J, Clerici G, Apfel C. A randomized, double-blind study to evaluate the efficacy and safety of three different doses of palonosetron versus placebo in preventing postoperative nausea and vomiting over a 72-hour period. Anesth Analg 2008; 107: 439-44.

6. Candiott KA, Kovac AL, Melson TI, Clerici G, Joo Gan T. A randomized, double-blind study to evaluate the efficacy and safety of three different doses of palonosetron versus placebo for preventing postoperative nausea and vomiting. Anesth Analg 2008; 107: 44551.

7. Yang LP, Scott LJ. Palonosetron: in the prevention of nausea and vomiting. Drugs 2009; 69: 2257-78.

8. Stoltz R, Cyong JC, Shah A, Parisi S. Pharmacokinetic and safety evaluation of palonosetron, a 5-hydroxytryptamine-3 receptor antagonist, in U.S. and Japanese healthy subjects. J Clin Pharmacol 2004; 44: 520-31. 
9. White LA, Vanarase M, Brockbank K, Barrett RF. Patient-controlled analgesia and postoperative nausea and vomiting: efficacy of a continuous infusion of ondansetron. Anaesthesia 2001; 56: 365-9.

10. Apfel CC, Laara E, Koivuranta M, Greim CA, Roewer N. A simplified risk score for predicting postoperative nausea and vomiting: conclusions from cross-validations between two centers. Anesthesiology 1999; 91: 693-700.

11. Kovac AL. Prevention and treatment of postoperative nausea and vomiting. Drugs 2000; 59: 213-43.

12. Lerman J. Surgical and patient factors involved in postoperative nausea and vomiting. Br J Anaesth 1992; 69(7 Suppl 1): S24-32.

13. Walder B, Schafer M, Henzi I, Tramer MR. Efficacy and safety of patient-controlled opioid analgesia for acute postoperative pain. A quantitative systematic review. Acta Anaesthesiol Scand 2001; 45: 795-804.

14. Tramer MR, Walder B. Efficacy and adverse effects of prophylactic antiemetics during patient-controlled analgesia therapy: a quantitative systematic review. Anesth Analg 1999; 88: 1354-61.

15. Bunce KT, Tyers MB. The role of 5-HT in postoperative nausea and vomiting. Br J Anaesth 1992; 69(7 Suppl 1): S60-62.

16. Rojas C, Stathis M, Thomas AG, Massuda EB, Alt J, Zhang J, et al. Palonosetron exhibits unique molecular interactions with the 5- $\mathrm{HT}_{3}$ receptor. Anesth Analg 2008; 107: 469-78.

17. Rojas C, Li Y, Zhang J, Stathis M, Alt J, Thomas AG, et al. The antiemetic 5- $\mathrm{HT}_{3}$ receptor antagonist palonosetron inhibits substance P-mediated responses in vitro and in vivo. J Pharmacol Exp Ther 2010; 335: 362-8.
18. Habib AS, Gan TJ. Evidence-based management of postoperative nausea and vomiting: a review. Can J Anaesth 2004; 51: 326-41.

19. Tramer MR, Reynolds DJ, Moore RA, McQuay HJ. Efficacy, doseresponse, and safety of ondansetron in prevention of postoperative nausea and vomiting: a quantitative systematic review of randomized placebo-controlled trials. Anesthesiology 1997; 87: 1277-89.

20. Choi DK, Chin JH, Lee EH, Lim OB, Chung CH, Ro YJ, et al. Prophylactic control of post-operative nausea and vomiting using ondansetron and ramosetron after cardiac surgery. Acta Anaesthesiol Scand 2010; 54: 962-9.

21. Lim SM, Kim JY, Kang H, Baek CW, Park JW, Jung YH, et al. The effects of continuous infusion of ondansetron on postoperative nausea and vomiting in patients receiving IV-patient controlled analgesia following gynecological surgery. Korean J Anesthesiol 2008; 55: 176-81.

22. Park SK, Cho EJ. A randomized, double-blind trial of palonosetron compared with ondansetron in preventing postoperative nausea and vomiting after gynaecological laparoscopic surgery. J Int Med Res 2011; 39: 399-407.

23. Moon YE, Joo J, Kim JE, Lee Y. Anti-emetic effect of ondansetron and palonosetron in thyroidectomy: a prospective, randomized, double-blind study. Br J Anaesth 2012; 108: 417-22.

24. Bhattacharjee DP, Dawn S, Nayak S, Roy PR, Acharya A, Dey R. A comparative study between palonosetron and granisetron to prevent postoperative nausea and vomiting after laparoscopic cholecystectomy. J Anaesthesiol Clin Pharmacol 2010; 26: 480-3. 